\title{
An experimental model for the study of craniofacial deformities ${ }^{1}$
}

\author{
Modelo experimental para o estudo de deformidades craniofaciais
}

\author{
André de Mendonça Costa ${ }^{\mathrm{I}}$, Gerson Shigeru KobayashiI, Daniela Franco Bueno ${ }^{\mathrm{III}}$, Marília Trierveiler Martins ${ }^{\mathrm{IV}}$, Marcus de \\ Castro Ferreirav $^{\text {, }}$ Maria Rita Passos-Bueno ${ }^{\text {VI }}$, Nivaldo AlonsovII \\ ${ }^{\mathrm{I}} \mathrm{PhD}$, Plastic Surgeon, University of Health Sciences (UNCISAL), Alagoas, Brazil. \\ ${ }^{\text {II }}$ Fellow Master degree, Institute of Biosciences, USP, São Paulo, Brazil. \\ ${ }^{\text {III }} \mathrm{PhD}$, Institute of Biosciences, USP, São Paulo, Brazil. \\ IV PhD, Associate Professor, Department of Oral Pathology, School of Dentistry, USP, São Paulo, Brazil. \\ ${ }^{v}$ PhD, Full Professor, Head of Plastic Surgery, Division of Plastic Surgery, Department of Surgery, FMUSP, São Paulo, Brazil. \\ ${ }^{\text {VI }} \mathrm{PhD}$, Full Professor, Institute of Biosciences, USP, São Paulo, Brazil. \\ ${ }^{\text {VII }} \mathrm{PhD}$, Associate Professor, Division of Plastic Surgery, Department of Surgery, FMUSP, São Paulo, Brazil.
}

\begin{abstract}
Purpose: To develop an experimental surgical model in rats for the study of craniofacial abnormalities. Methods: Full thickness calvarial defects with 10x10-mm and 5x8-mm dimensions were created in 40 male NIS Wistar rats, body weight ranging from 320 to $420 \mathrm{~g}$. The animals were equally divided into two groups. The periosteum was removed and dura mater was left intact. Animals were killed at 8 and 16 weeks postoperatively and cranial tissue samples were taken from the defects for histological analysis. Results: Cranial defects remained open even after 16 weeks postoperatively. Conclusion: The experimental model with $5 \times 8$-mm defects in the parietal region with the removal of the periosteum and maintenance of the integrity of the dura mater are critical and might be used for the study of cranial bone defects in craniofacial abnormalities.
\end{abstract}

Key words: Bone Regeneration. Craniofacial Abnormalities. Parietal Bone. Rats.

\section{RESUMO}

Objetivo: Desenvolver um modelo experimental em ratos para o estudo de deformidades craniofaciais. Métodos: Foram realizados defeitos ósseos de espessura total com diâmetro de 5 × $8 \mathrm{~mm}$ e 10 x 10mm na calota craniana em 40 ratos, machos, NIS Wistar, com peso de 320 a $420 \mathrm{~g}$ divididos igualmente em dois grupos. O periósteo foi retirado e a dura-máter mantida intacta. Os animais foram sacrificados na $8^{\mathrm{a}}$ e $16^{\mathrm{a}}$ semana de pós-operatório e amostras de tecido ósseo foram extraídas para realização da análise histológica. Resultados: Os defeitos cranianos permaneceram abertos mesmo após 16 semanas após a cirurgia. Conclusão: O modelo experimental com defeitos de $5 \times 8 \mathrm{~mm}$ na região parietal, com remoção do periósteo e manutenção da integridade da dura-máter são considerados críticos, e poderá ser utilizado para o estudo dos defeitos ósseos cranianos nas anomalias craniofaciais.

Descritores: Regeneração Óssea. Anormalidades Craniofaciais. Osso Parietal. Ratos.

${ }^{1}$ Research performed at Division of Plastic Surgery, Department of Surgery, University of São Paulo Medical School (FMUSP) and Institute of Biosciences, University of São Paulo (USP), Brazil.

\section{Introduction}

Cranial bone defects caused by severe trauma, infection, neoplasms, surgery or congenital deformity continue to represent a major challenge to plastic reconstructive surgery ${ }^{1}$. Large cranial defects are associated with high morbidity and mortality in the neonatal period, and therefore their treatment is important not only to improve aesthetic appearance, but mostly to reestablish the rigid protection of the underlying brain ${ }^{2,3}$.

Bone autograft transplantation is still the most used method for the reconstruction of cranial bone loss to date. However, this method is inadequate for critical size defects ${ }^{4}$ which are characterized for remaining open during the lifetime of the animal with no spontaneous bone regeneration.

Although a wide variety of bone grafts and implants have been evaluated in various species for experimental animal models, there is little consistency among investigators regarding the choice of an appropriate animal model ${ }^{5}$. Critical size bone defects represent attractive models to study bone healing because, by definition, they do heal without intervention ${ }^{5}$. The diameter of critical size defects varies greatly among animals of the same species across different studies ${ }^{6}$.

The aim of this study is to determine the ideal critical size bone defect in rats using specific surgical techniques. 


\section{Methods}

Four-month-old male NIS Wistar rats (Rattus norvegicus albinus), body weight ranging from 320 to $420 \mathrm{~g}$, were used for this study. The Animal Research Ethics Committee at the University of Sao Paulo approved the experimental protocol. The animals were individually kept in separate cages in a ventilated stand, under standardized air and light conditions at a constant temperature of $22^{\circ} \mathrm{C}$ with a 12-hour light/day cycle. They had free access to tap drinking water and standard laboratory food pellets.

The animals were anesthetized with an intraperitoneal injection $(0.3 \mathrm{~mL} / 100 \mathrm{~g}$ of body weight $)$ with a combination of ketamine hydrochloride $(5 \%)$ and xylazine $(2 \%)$.

The dorsal region of cranium was shaved and the head of the rats was positioned in a cephalostat during the operative procedure (Figure 1) and aseptically prepared for surgery.

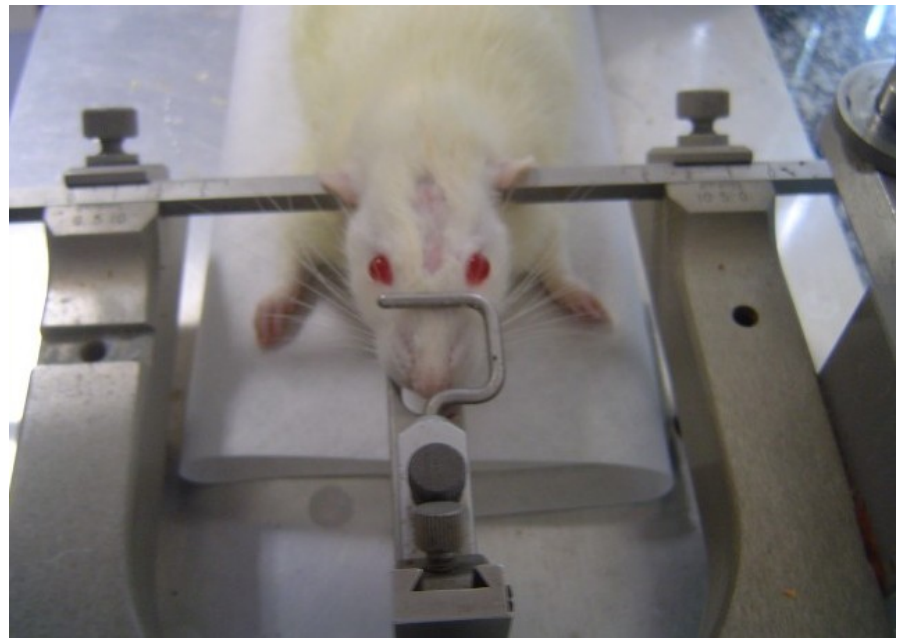

FIGURE 1 - Animals positioned in the cephalostat

A 20-mm midline skin incision was performed from the nasofrontal area to the external occipital protuberance. The skin and underlying tissues, including the temporalis muscles, were reflected laterally to expose the full extent of the calvaria. The periosteum surrounding the defect was removed to prevent periosteum osteogenesis (Figure 2).

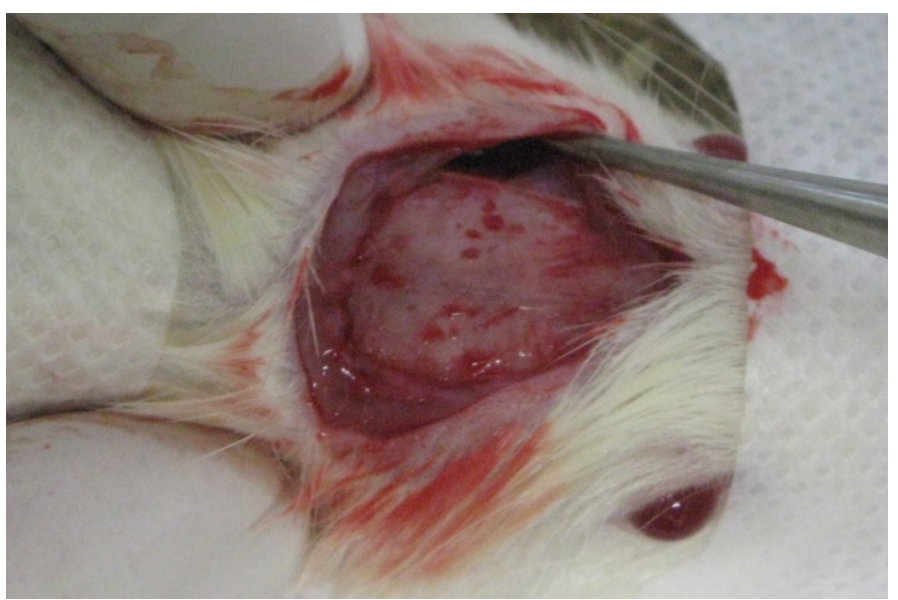

FIGURE 2 - Exposure of the calvaria
The animals were randomly divided into two groups (20 in each group), as follows: in group 1, two 5x8-mm full thickness bone skull defects were created bilaterally in the dorsal part of the parietal bone, lateral to the sagittal suture (Figure 3), whereas in group 2, one 10x10-mm full thickness bone defect through the sagittal suture was created (Figure 4). The cranial defect was created using a drill with a micromotor under constant irrigation with sterile saline solution to prevent bone overheating. Additionally, in order to prevent dura mater damage an optical microscope was used during the osteotomy and the bone fragment was cautiously detached. The flap of each animal was closed with mononylon 4-0 sutures. The animals were killed 8 and 16 weeks postoperatively with inhaled $\mathrm{CO}_{2}$ and the calvaria was removed for histological analysis (Figure 5).

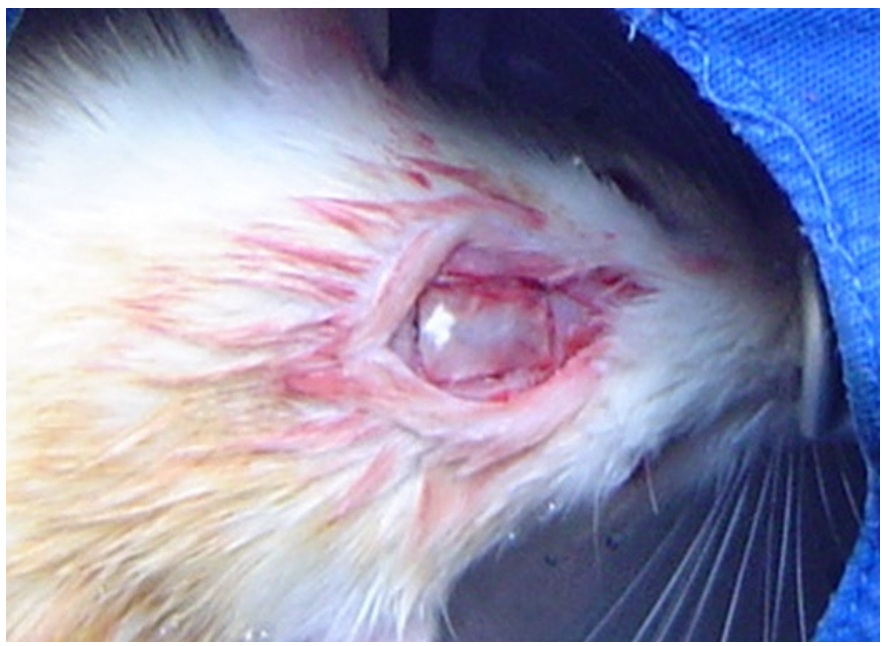

FIGURE 3 - 10x10mm cranial defect

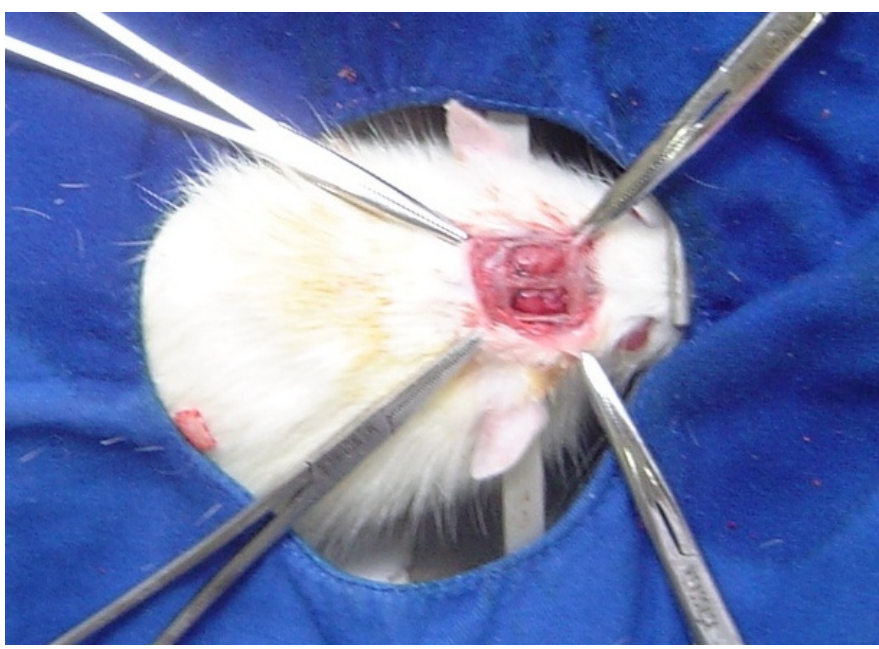

FIGURE 4 - 5x8mm cranial defect 


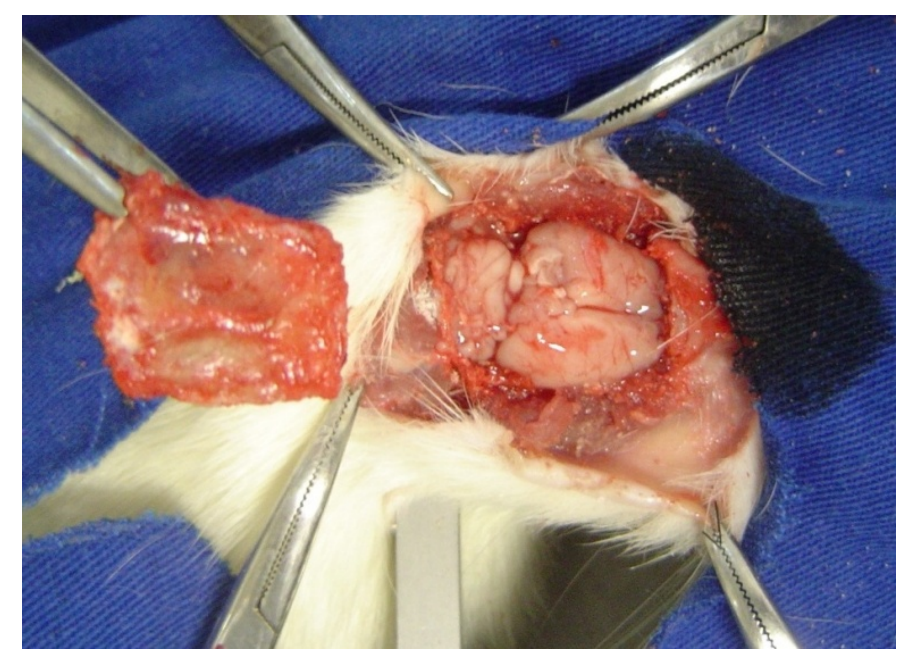

FIGURE 5 - Biopsy collection for histological analysis

\section{Histological preparation}

The studied tissue samples were fixed in $10 \%$ formalin for 24 hours, decalcified in 5\% formic acid for 48 hours, and paraffin-embedded. The 5-micron sections were stained with hematoxylin and eosin and examined under a light microscope. This analysis was qualitative and analyzed either the presence or absence of mineralized tissue.

\section{Results}

Group $1(\mathrm{~N}=20)$ : sagittal sinus laceration to a greater or lesser degree was observed in 9 animals during the removal of the calvarial bone. Two animals died during the first 24 postoperative hours and 4 animals had laceration of the dura mater during osteotomy. All the animals that died during the first 24 hours were immediately replaced by other animals. There was no osseous consolidation of the calvaria bone appreciable by gross and histological examination after 8 weeks postoperatively. After 16 weeks there was little bone regeneration commencing from the defect margins. None of the animals presented osseous defect closure until the end of the observation period, not even reaching $50 \%$ of the defect area (Figure 6).

Group $2(\mathrm{~N}=20)$ : no evidence of sagittal sinus laceration, bleeding or death of animals either during or after surgery. A similar scenario as in the group 1 was observed through gross and histological examination where none of the animals presented osseous defect closure until the end of the observation period, not even $50 \%$ of the defect area (Figure 6).
A

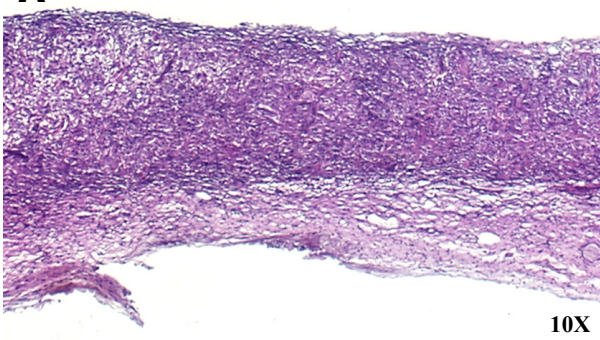

B

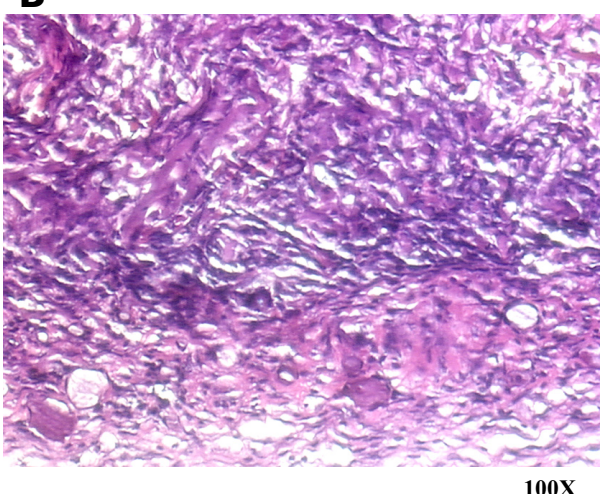

$A^{\prime}$

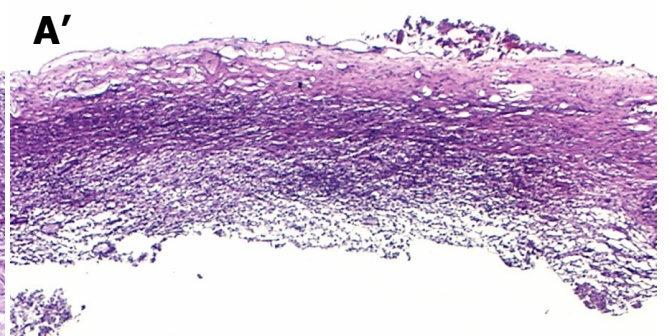

10X

\section{$B^{\prime}$}

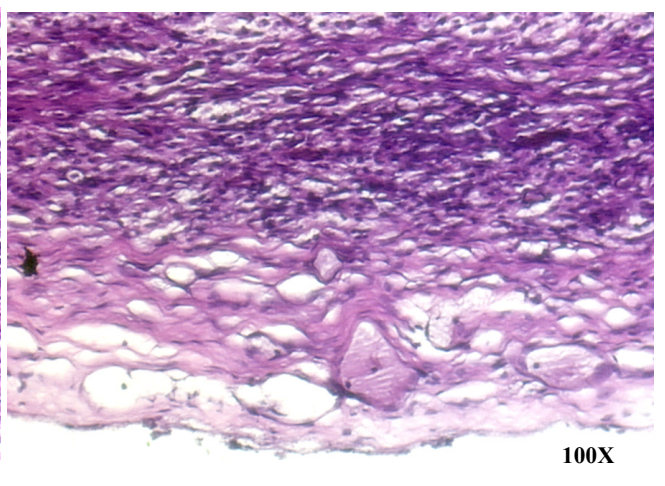

FIGURE 6 - Comparative histological analysis of cranial defects at 8 and 16 weeks postoperatively.

A, B: 8 weeks and A', B': 16 weeks 
No evidence of infection or wound dehiscence occurred postoperatively in both groups.

\section{Discussion}

Calvarial was used for studying regenerative critic size bone defect because the calvaria is an anatomic area of limited mechanical stress and relative stability of the surrounding structures, including intact calvarial margins, underlying the dura mater and overlying temporalis and frontalis muscles, creating a protected environment in which it is possible to study the interactions between new bone constructs and in situ bone ${ }^{7}$.

Freeman et al. ${ }^{8}$ and Turnbull et al. ${ }^{9}$, the first to attempt the study critical size defects in rat calvaria, demonstrated that 2-mm-diameter defects created through the parietal bone failed to heal within 12 weeks. Mulliken et al. ${ }^{10}$ determined that 4-mmdiameter defects were unsuccessfully healed over a 6-month period. Takagi et al. ${ }^{11}$ determined that 8 -mm-diameter defects created in the calvaria were reduced to $5 \mathrm{~mm}$ in diameter within four weeks. No further healing of the wound was observed after 12 weeks. However, these authors did not provide any surgical details for an experimental animal model.

Another important characteristic in determining an experimental model is the age of animals. Various animal models comparing the healing potential of calvarial defects in juvenile versus adult animals have been described in the literature. As early as 1939, Sutro and Jacobson reported that juvenile rats had a greater ability to heal 3-mm calvarial defects after 5 months compared with adults ${ }^{12}$. Longaker et al. ${ }^{13}$ demonstrated that juvenile (6-day-old) mice have a significantly greater ability to reossify calvarial defects compared with adult (60-day-old) mice after 8 weeks of healing. Therefore, spontaneous regeneration is known to be slower in adult animals than in young animals, and accordingly the development of an experimental a model focusing on the study of craniofacial deformities animals must be conducted with adult animals.

The periosteum was removed during bone defect creation because the periosteum is believed to be a key factor in the cranial bone healing of critical size defects. According to other authors ${ }^{14}$, the periosteum remaining at the osteotomy site assumes an essential role in determining the diameter of long-bone critical size defects.

The integrity of dura mater described in this study is another important aspect that should be considered. Hobar et al. ${ }^{15}$ emphasize the importance of the dura mater in the regeneration of critical defects in pigs and raise a correlation of this role to the age of the animal. Similarly, the injury is believed to interfere in the stimulus for bone formation when studying the role of stem cells in bone repair, for example. That is, this injury can induce the formation of nervous tissue, since introducing undifferentiated stem cells can differentiate them into cells of the nervous tissue, muscle, bone, cartilage and fat.

The 16-week time point was used for being previously demonstrated as sufficient length of time to allow measurable bony repair in other models of adult calvarial defect healing ${ }^{15,16}$.

It is also emphasized that the use of a cephalostat specially developed for rats and the optical microscope allowed a more precise osteotomy without adjacent lesions. The specially designed cephalostat kept the animal in a static position as observed in human cranial surgeries and the optical microscope allowed direct viewing during the osteotomy preventing any lesions in the dura mater.

After the development of bone defects of varying sizes to establish an experimental model in order to examine craniofacial deformities, a rectangular-shaped $(5 \times 8 \mathrm{~mm})$ critical size defect was chosen and created in the biparietal area, resulting in no spontaneous closure of the bone defect, not even reaching $50 \%$ of the area after 16 weeks of observation. Whereas, to achieve greater bone defects $(10 \times 10 \mathrm{~mm})$, there was a laceration to a greater or lesser degree in the sagittal sinus causing high morbidity and exposing the animals to the risk of bleeding and infections of the central nervous system, besides requiring cranial sutures, which have a known biomolecular behavior different from other regions of the craniofacial bone ${ }^{17}$.

This experimental model seems to be useful in evaluating the efficacy of stem cells isolated from a variety of organs and tissues in order to close critical size cranial defects. In our previous work, human dental pulp stem cells and human musclederived stem cells were found to be able of closing critical size rat calvarial defects using this experimental surgical protocol ${ }^{18,19}$.

\section{Conclusion}

The $5 \times 8-\mathrm{mm}$ rectangular defect in the biparietal bone of adult rats with periosteum removal and dura mater integrity can be considered a critical cranial defect and might be used as an experimental model for the study of craniofacial deformities.

\section{References}

1. Shang Q, Wang Z, Liu W, Shi Y, Cui L, Cao Y. Tissue-engineered bone repair of sheep cranial defects with autologous bone marrow stromal cells. J Craniofac Surg. 2001;12(6):586-95.

2. Dahlin C, Linde A, Gottlow J, Nyman S. Healing of bone defects by guided tissue regeneration. Plast Reconstr Surg 1988;81(5):672-6.

3. Grantham EC, Landis HP. Cranioplasty and the post-traumatic syndrome. J Neurosurg. 1948;5(1):19-22.

4. Manson PN, Crawley WA, Hoopes JE. Frontal cranioplasty: risk factors and choice of cranial vault reconstructive material. Plast Reconstr Surg. 1986;77(6):888-904.

5. Schmitz JP, Hollinger JO. The critical size defect as an experimental model for craniomandibulofacial nonunions. Clin Orthop Relat Res. 1986;205:299-308.

6. Bosch C, Melsen B, Vargervik K. Importance of the critical-size bone defect in testing bone-regenerating materials. J Craniofac Surg. 1998;9(4):310-6.

7. Mankani MH, Kuznetsov SA, Wolfe RM, Marshall GW, Robey PG. In vivo bone formation by human bone marrow stromal cells: reconstruction of the mouse calvarium and mandible. Stem Cells. 2006;24(9):2140-9.

8. Freeman E, Turnbull RS. The value of osseous coagulum as a graft material. J Periodontal Res. 1973;8(4):229-36.

9. Turnbull RS, Freeman E. Use of wounds in the parietal bone of the rat for evaluating bone marrow for grafting into periodontal defects. J Periodontal Res. 1974;9(1):39-43.

10. Mulliken JB, Glowacki J. Induced osteogenesis for repair and construction in the craniofacial region. Plast Reconstr Surg. 1980;65(5):553-60.

11. Takagi K, Urist MR. The reaction of the dura to bone morphogenetic protein (BMP) in repair of skull defects. Ann Surg. 1982;196(1):100-9.

12. Sirola K. Regeneration of defects in the calvaria. An experimental study. Ann Med Exp Biol Fenn. 1960;38(Suppl 2):1-87. 
13. Aalami OO, Nacamuli RP, Lenton KA, Cowan CM, Fang TD, Fong KD, Shi YY, Song HM, Sahar DE, Longaker MT. Applications of a mouse model of calvarial healing: differences in regenerative abilities of juveniles and adults. Plast Reconstr Surg. 2004;114(3):713-20.

14. Narang R, Laskin DM. Experimental osteogenesis at fracture sites and gaps. J Oral Surg. 1976;34(3):225-31.

15. Hobar PC, Schreiber JS, McCarthy JG, Thomas PA. The role of the dura in cranial bone regeneration in the immature animal. Plast Reconstr Surg. 1993;92(3):405-10.

16. Krebsbach PH, Mankani MH, Satomura K, Kuznetsov SA, Robey PG. Repair of craniotomy defects using bone marrow stromal cells. Transplantation. 1998;66(10):1272-8.
17. Alberius P, Isaksson S, Klinge B, Sjogren S, Jonsson J. Regeneration of cranial suture and bone plate lesions in rabbits. Implications for positioning of osteotomies. J Craniomaxillofac Surg. 1990;18(6):271-9.

18. Bueno DF, Kerkis I, Costa AM, Martins MT, Kobayashi GS, Zucconi E, Fanganiello RD, Salles FT, Almeida AB, do Amaral CE, Alonso N, Passos-Bueno MR. New source of muscle-derived stem cells with potential for alveolar bone reconstruction in cleft lip and/or palate patients. Tissue Eng Part A. 2009;15(2):427-35.

19. de Mendonca Costa A, Bueno DF, Martins MT, Kerkis I, Kerkis A, Fanganiello RD, Cerruti H, Alonso N, Passos-Bueno MR. Reconstruction of large cranial defects in nonimmunosuppressed experimental design with human dental pulp stem cells. J Craniomaxillofac Surg. 2008;19(1):204-10.

\section{Correspondence:}

André de Mendonça Costa

R. Joaquim Nabuco, $81 / 1^{\circ}$ andar

57051-410 Maceió - AL Brazil

andredemendonca@usp.br 